DEPARTMENT OF ECONOMICS

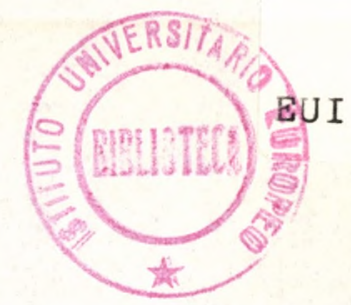

$\begin{array}{lllllll}\text { E U I WOR K N G P A E R No.84/127 } & \text { W }\end{array}$

FINANCIAL MODEL BUILDING AND FINANCIAL MULTIPLIERS OF THE DANISH ECONOMY

by

Jesper Jespersen

The author is Jean Monnet Fellow at the European University Institute 1984/85. Hereby I would like to thank stud.polit. Lone Neerhöj and stud.polit.Niels Lehde Pedersen for their effort to put some order in chaos. A grant from the Danish council for Social Research made this study possible.

Remaining errors can only be blamed on the author.

The paper has been presented at the seminar on Macroeconomic Modelling in the Nordic countries, Copenhagen, October 84. 
Al1 rights reserved

No part of this paper may be reproduced in any form without permission of the author

(C) Jesper Jespersen

Printed in Italy in December 1984

European University Institute

Badia Fiesolana

50016 San Domenico (Fi)

Italy 
FINANCIAL NODEL BUILDING AND FINANCIAL MULTIPLIERS OF THE

DANISH ECONOMY

SUMMARY: The tradition of integrating real sector and financial sector models is not very established. But in the wake of the "deficit dispute" the necessity of such an integration has become more and more obvious. A consistent financial model requires a double entry accounting system for each sector involved. Data are difficult to obtain in many cases. A Danish financial model has been estimated on quarterly data (1974-1982)--with the financial wealth of the private sector and the bond rate as the most important ties to "the real world". The most uncommon feature of the model is that the bond rate is determined explicitly as a market clearing price. The abilities of the model are analyzed. Multipliers without and with real sector feedback are calculated. Not surprisingly, the feedback from investments and consumption changes the size of the multipliers considerably depending on the degree of liguidity sterilization. 
Introduction

This paper undoubtedly raises more questions than it settles. Anyhow, for the purpose of communication the intermediate findings may be of some interest.

The content of the paper will be as follows. Firstly, a short historical perspective on financial sector model building within macroeconomic models is given. Secondly, some of the methodological problems involved are discussed. Thirdly, the specific Danish features of the financial sector and how I have approached them shall be dealt with in some length under the headings: The theoretical framework, Empirical findings, and financial multipliers without and with feedback from the real sector of the economy.

\section{A historical perspective}

The childhood of econometric models contemporized with that period in economic thinking where "money did not matter". Accordingly, nobody really cared about any financial relation within the econometric models for the first decade or more after the war.

For many reasons this situation could not continue unchanged. The real sector grew larger and larger measured by the number of equations and more and more financial variables showed up on the right-hand side of the equations.

This led to the first attempts at making a few financial variables endogenous. Of specific interest was the long-term rate of interest and the (financial) wealth. But as a consequence of the fierce attacks from the monetarist school one 
does also see the demand for money equation more and more often. One common feature of these very first incorporations of financial response into the real sector models was the ad hoc character of these attempts. I think not before the (late) sixties Brainard \& Tobin (among others) provided the financial sector model-builder with a satisfactory theoretical framework for the construction of the financial sector within an econometric model. Since then a vast number of such models has been set up with Branson, 1968, as one of the pioneers.

Within the Nordic countries a few attempts at integrating the real and the financial sectors have been made. 1) one rather successful approach has been provided by Blomgren-Hansen, 1983, related to the Danish Economy. He took as the starting point a rather detailea balance sheet of the financial sector with all real sector variables as being exogenous. Then one by one he has endogenized almost all the most important real variables-and he is by now close to completing this model, named NATAN. One could also point to the work done by Rosted, 1980. He put two already existing models together: ADAM for the real sector and NATAN for the financial one. ${ }^{2)}$

\section{Methodological Reflections}

According to the literature any financial (sub) model should have a firm founding in a double-entry accounting system matching debtors and creditors. The variables going into such a balance sheet model are stocks--in contrast to the flow of funds account.

One may ask in what way these stock variables can be properly measured. For instance in NATAN all variables are calcu- 
lated by accumulating flows to the value of the stock at the beginning of the period. This means that any change in a stock variable mirrors the corresponding flow of cash. But through time the value of stocks may change due to changes in prices. Especially in relation to the huge bond market the actual value of the stock of bonds differs quite a lot from the accumulated flow value. This problem of valuation is also present when stocks denominated in foreign currency are considered.

The theory tells us that it is the actual (or expected) value that matters--the outstanding example is private wealth. From a practical point of view capital gains and losses do make the entire balance system more complicated-without being sure that one is able to obtain the theoretically correct measurement, anyhow.

In fact that is a general problem in the field of econometric research that one has seldom any observation of expected (or anticipated) values. Take for instance the expected return on financial (or real) assets. There are in the literature presented a number of solutions, but either they require that very tough assumptions be fulfilled or they are of an ad-hoc character.

The Structure of the Financial Sector Model (FINDAN)

A model of the Danish financial sector estimated on quarterly data $(1974.1$ - 1982.4) has been set up. There are six sectors :

P - Private non-banking sector (households and firms)

B - Private banks (financial institutions where liabilities 
are regarded as money)

L - Local authorities (that hold accounts in private banks)

G - Central government (and other authorities that hold accounts at the central bank)

N - Central bank (Danmarks Nationalbank, Hypotekbanken, Girokontoret and a few minor institutions)

F - Foreign sector

There are five different kinds of assets/liabilities:

MB - Primary liquidity (monetary base)

DTD - Demand (DD) and time (TD) deposits added together

LO - Loans

BO - Bonds (including Treasury Bills)

VR -- Foreign exchange

In principle a $6 \times 6$ matrix could be established for each asset/liability; but in practice all sectors do not issue all 5 kinds of liabilities (or hold all 5 assets). For instance, foreign exchange can only be issued by the foreign sector and may only legally be held by private (and central) banks.

Making the entire variable-name the letter of the creditor sector is pre-set and that of the debtor sector is post-set. For instance, 'FLOP' means the accumulated amount of foreign loans to the private non-banking sector.

With five assets/liabilities and six sectors one could at the most expect 25 separate prices. Dependent on the structure of the financial markets, this number is narrowed down. For instance, all bonds, independent of the holder or issuer, are regarded as one homogeneous asset; accordingly, there is only one bond rate. 
a) Concerning primary liquidity (MB) one could say that to firms and households the price is 1 (one), and the nominal rate of interest is zero. On the other hand regarding banks there is a positive price--often related to the discount rate (IDI) fixed by the central bank. ${ }^{3}$ )

b) The rate of interest on demand and time deposits (IDD, ITD) is fixed by the banks more or less mutually. This means that one finds at these markets a kind of monopolistic price setting. Up till now the rate of interest on deposits has been rather closely linked to the discount rate. ${ }^{4)}$

C) Concerning bank loans the situation is very much the same. Although, when the ceiling on loans was lifted in 1980 the discrepancy between deposit rates and loan rates started to narrow somewhat. Anyhow, bank rates are not settled on conditions comparable with perfect competition --quite the opposite.

Accordingly, banks do accept deposits and grant loans at the current rates without any hesitation (except for periods where quantitative restrictions are imposed on them).

d) Quite the contrary situation is ruling at the bond market. That is a very competitive market with many small demanders and suppliers--except for the central bank. This has a dominating role due to its position of being the monetary authority and the selling agent of government bonds. ${ }^{5}$ )

e) Foreign exchange rate and interest rate are assumed to be determined exogenously. 
The Behavioural Equations of the Financial Sector Model

In this part I will only present the more general findings --the more specific details you will find in Annex 1. The period of estimation is 1974.1 - 1982.4.

The common background for all equations is taken in a conventional portfolio model, like for instance Friedman, 1978.

The private non-bank sector demands high-powered money, bank deposits and bonds (private and governmental) and issues bank loans, mortgage bonds and foreign loans. Each asset equation depends on private financial wealth, relative rates of return, income and exchange rate variations. Especially in relation to the demand for bank deposit equation I have learned a lot from Christensen, 1984. The liability equations do also depend upon the development in financial wealth, but only a very weak impact from changes in relative borrowing costs to changes in debt instruments could be detected. The statistical performance of the foreign loans equation was so poor that it was decided to make the equation the "implicit" one--derived from the other equations and the balance-sheet requirement.

According to these empirical findings one can calculate the, ceteris paribus, effect of an increase in private financial wealth of, say, 10 bill. Dkr. in 1982:

Demand for bank deposits

1.6 bill. $\mathrm{kr}$.

Demand for bonds

0.6 bill. $\mathrm{kr}$.

Decrease of loans in banks

1.0 bill. $\mathrm{kr}$.

Decrease of bond debt

5.0 bill. kr.

(Decrease in foreign debt

1.8 bill. kr.)

Total

10.0 bill. kr. 
The private sector seems more inclined to run down debt than to accumulate further assets when the financial wealth increases. ${ }^{6)}$

The second endogenous sector is the financial one--represented by commercial and saving banks. But due to the pricesetting behaviour, explained above, of the banking sector the balance sheet of the banks is to a large extent quantitatively determined by the behaviour of households and firms with regard to assets and liabilities. Banks are willing, at least in the shorter run, to accept whatever amount of deposits and loans that is asked for (except for periods with quantitative regulations) on the ruling price (and security) conditions.

Although banks are free to change the rate of interest on deposits and loans, there has up till now been a close tie between the discount rate and the bank rates.

When banks got excess reserves they have in the estimation period on average bought bonds for app. $2 / 5$ of the amount and increased their unborrowed reserves for the rest.

The four remaining sectors (local authorities, central government, central bank and the foreign sector) are regarded as exogenous to the private one. Accordingly, the only equations going into these sectors are identities, and institutional relations, and rules of financing deficits.

The $n^{\prime}$ th equation of the model which is suppressed due to the overall balance-sheet requirement, is decided to be the sector balance of the central bank. Accordingly, this equation will be implicit in the entire model. 
Empirical Results

The variable that attracts the most interest in the Danish context is without doubt the bond rate. With the market-clearing approach to the bond market it was impossible to say in advance whether or not it would be determined reasonably well. Using a single equation approach, where the right-hand side variables are given historical values the bond rate is within the period of estimation tracked within the boundaries of \pm 2 percentage points.

The results coming from a simulation of the entire model through the estimation period give the following picture, cf. figure 1 .

Unfortunately, prolonging the simulation period into 1983 creates some difficulties. The pronounced fall in the nominal bond rate from 19.7 pct. in the 4 th quarter of 1982 to 13.8 pct. in the 2 nd quarter of 1983 is caught by the model only with a somewhat longer time lag.

Due to this state of affairs there will only be presented multipliers for the period of estimation.

\section{Multipliers}

Just to get a picture of how the financial markets interact within the model the following multiplier-simulations have been carried through:

1) Open Market Operations: Sale of 1 bill. Dkr. government bonds in 1978.1 (corresponding to app. 3 bill. Dkr. in 1984)

2) Raising the discount rate by 1 percentage point from 1978.1 onwards 
3) A higher interest rate abroad (represented by the DM-rate). Nultipliers are calculated for the period 1978.1 - 1982.4. The model seems to be stable, but oscillating around a "moving equilibrium". The latter phenomenon is partly due to the fact that all stocks are measured in nominal terms and nearly doubled through the simulation period.

ad 1) 1 bill. kr. extra government bonds are assumed to be sold each quarter. This adds up to 22 bill. kr. higher supply of government bonds (BOGXU) at the end of the period. The bond rate reacts by rising app. 0.2 percentage point every quarter-leaving the level of interest somewhat 4 percentage points higher in 1982.4 compared with the control solution, cf. figure 2 .

Had it only been a one-shot increase in the sale of bonds of 1 bill. $\mathrm{kr}$. in 1978.1 the picture would have been a little different. Within the same quarter the interest rate goes up with .44 percentage point. In the following guarters the portfolios adjust, which reduces the rate. In a five-year perspective the lasting effect is about .22 percentage point.

This rise of the bond rate is, of course, mainly due to the response of the private non-financial sector (P-sector). It gives some information on how the model interacts to detect the way the P-sector finances the purchase of the additional bonds. Taking the first example the P-sector ends up with an increased stock of bonds of the magnitude of 32.9 bill. kr. (not 22 bill. $\mathrm{kr}$. which one maybe would have expected from a more immediate view). This is due to the reaction of the banking sector (Bsector). This reduces the holdings of bonds when households and firms withdraw their deposits. This reaction of the banks puts of course an extra pressure on the bond rate. ${ }^{7}$ 
The way the P-sector changes its portfolio is partly to run down other assets (deposits in banks and cash) and partly by borrowing--especially abroad, cf. table 1:

Table $1 \quad$ How the P-sector finances the purchase of bonds

$$
\text { Bill. kr. }
$$

Reduction of deposits

17.0

Reduction of cash

0.9

Borrowing abroad

12.2

"Borrowing by itself" 8 )

0.7

Borrowing in banks

2.1

Increased resources

Table 1 also unveils that the effect on the exchange reserves is quite strong: app. 40 per cent of the purchase of bonds is financed (directly or indirectly) by borrowing abroad. In table 2 the reactions of the B-sector are shown:

Table 2

\section{The derived reactions of banks}

Bill. kr.

Reduction of deposits 17.0

Increased loans

$$
2.1
$$

Lack of resources

Sale of bonds 10.2

Reduced cash holdings

0.2

Increased borrowing in the central bank 
If banks had not been allowed to increase their borrowing in the central bank even more bonds would have had to change sector, which would have resulted in a further rise in the bond rate, but would also have drawn more foreign exchange to the country.

The amount of money reduces considerably due to the increased sale of government bonds. The fall in deposits of 17 bill. kr. corresponds to app. 10 percentage fall in the stock of money (1982.4)--at the "price" of 4 percentage points higher bond rate.

Linking the financial sector model (FINDAN) with the real sector

According to the results referred above an increased supply of government bonds of app. 2.5 bill. $\mathrm{kr}$. in 1978.1 would raise the bond rate with 1 percentage point (with a slightly downward trend). The consequences for the "real world" of such a higher bond rate are calculated by the use of SMEC III $^{9)}$ and summarized below in table 3 .

These yearly multipliers are converted into quarterly changes in a very primitive way. Anyway, the method used should at least secure consistency between the yearly and the quarterly effects, cf. annex 2 .

Before making a new simulation with the financial sector model it is of crucial importance to decide upon how the increased deficit of the public sector is financed. Two alternatives have been calculated:

1) money financing (no sterilization)

2) increased supply of government bonds amounting to the sum 
of the increased public sector deficit and reduced current account deficit (partial sterilization).

Table 3 "Real" effects of a 1 percentage point higher bond rate $\underline{1978}-1982$

change in:

GDP (Y)

Gross investm. (IF)

House building ( IH)

Current account (BBLBAL) ${ }^{1)}$

Public sector (STABAL)

Private sector $\begin{array}{lllll}1978 & 1979 & 1980 & 1981 & 1982\end{array}$

-

$\begin{array}{lllll}-47 & -851 & -1202 & -1486 & -1621\end{array}$

$\begin{array}{lllll}-130 & -1150 & -1320 & -1298 & -1111\end{array}$

$-3-592-524-439-369$

$\begin{array}{lllll}-133 & -701 & -975 & -1114 & -1094\end{array}$

$\begin{array}{lllll}-95 & -584 & -597 & -619 & -645\end{array}$

$+228+1285+1572+1733+1739$

Note: 1) A negative sign indicates a reduced deficit of the current account of the balance of payments.

Results are summarized in table 5. Here we see that the simulation without any feedback from the real sector (no. 3) goes in between the other two simulations. If the licuidity effect derived from reduced balance of payments' deficit and increased public sector deficit is not sterilized then the rate of interest starts to fall. After 12 quarters it is back at the starting level and is still falling. This also implies that the initially positive effect on capital import is reversed, mainly due to the increased amount of liquidity within the private sector.

on the other hand sterilizing the liquidity coming from the current account and the public sector, ef. column 2 in table 5 , makes the bond rate stay rather unchanced at the 1 percentage 


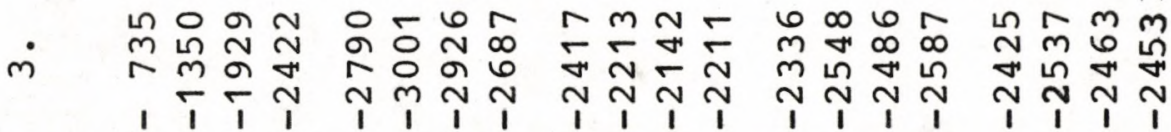

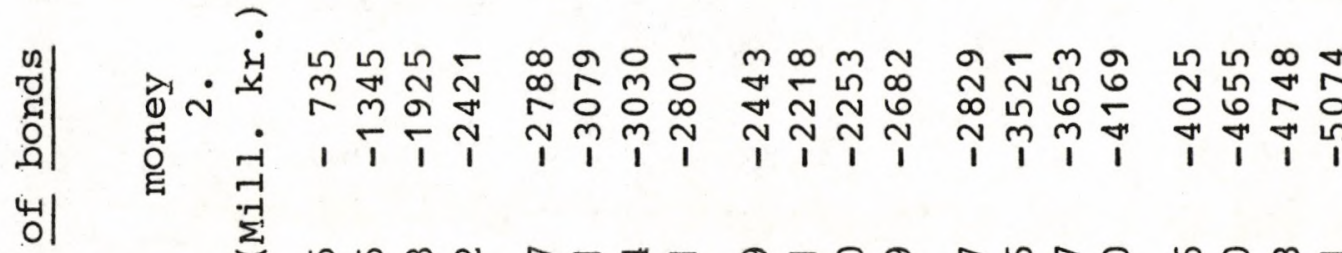

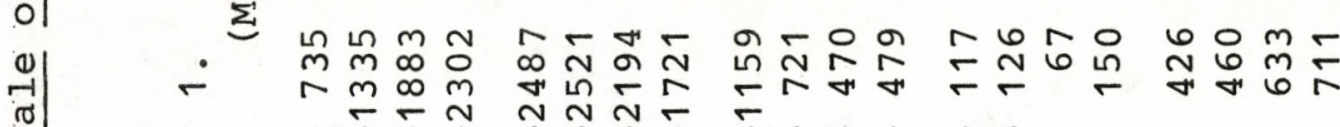

要 1 1

蕉|

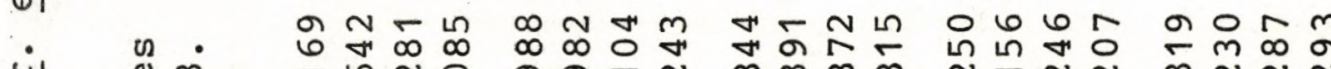

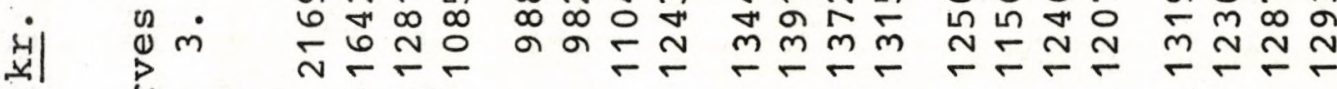

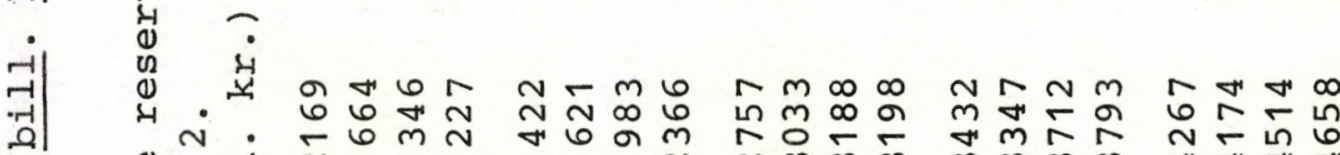

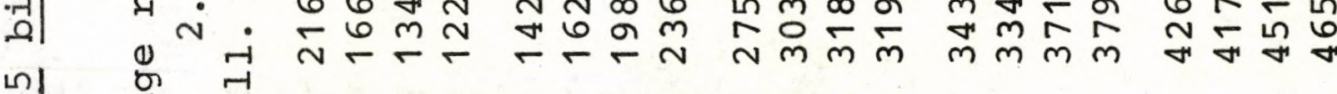

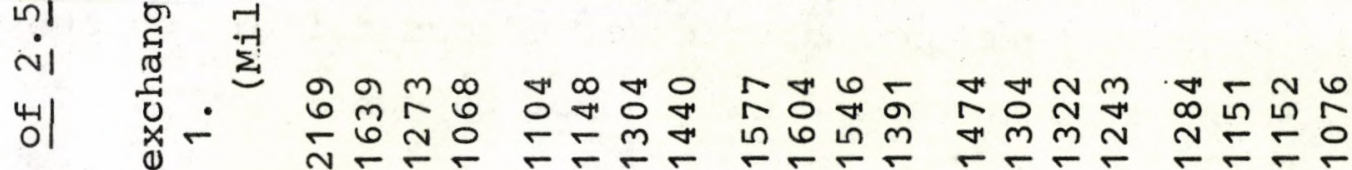

崩|

व)

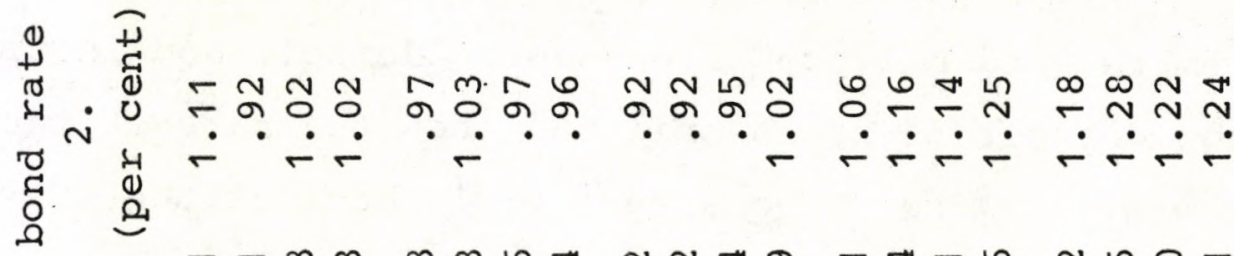
$\therefore$ ร

苟

$-$

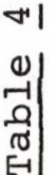

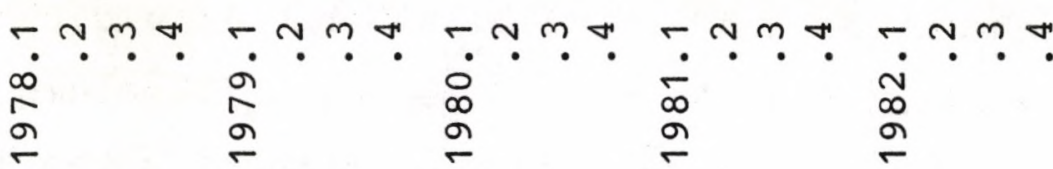


point higher level throughout the entire period. The lower level of activity due to the higher interest rate improves, of course, the current account, but the capital account is hardly improved at all. Especially when the demand for investment goods goes down it reduces the capital import.

Effects of changes in the discount rate and the foreign rate of interest

Multipliers showing the effects of a change in the discount rate and the foreign rate of interest (represented in the model by the rate on 3 months deposits in DM) are calculated without any feedback from the real sector.

But knowing that it is only the bond rate among the financial variables that has any significant effect within SMEC III, one can use the results obtained in table 5 to find the combined effects.

When the discount rate is raised the bond rate follows with some fluctuations app. half the way up. The foreign rate of interest has a somewhat weaker influence (if the discount rate is not raised contemporaneously): The bond rate changes only by one third at the maximum, and the lasting effect is around .2 . The capital import is changing by 1.5 bill. kr. pr. 1 percentage point the discount rate change and fluctuates between $1 / 2$ and 1 bill. $\mathrm{kr}$. when the foreign rate changes by 1 percentage point.

Also the demand for money seems to be rather volatile in the wake of a change in the short-term rate of interest. Further results are presented in table 5 below. 
Table 5 Multiplier effects of a 1 percentage point higher discount rate and foreign rate of interest (DM)

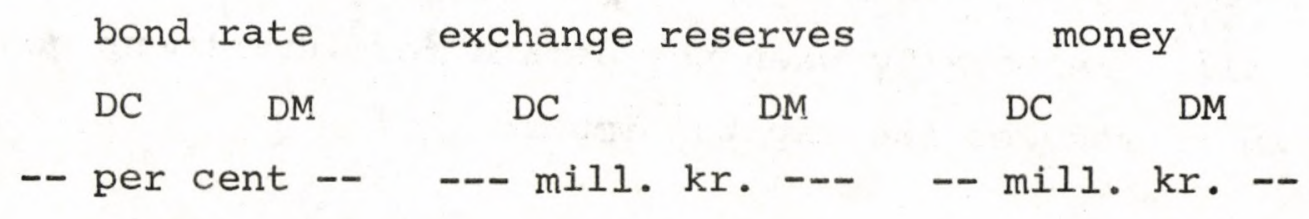

$\begin{array}{rrrrrrr}1978.1 & .50 & .14 & 1360 & -551 & 1021 & -932 \\ .2 & .46 & .24 & 1744 & -875 & 1825 & -1797 \\ .3 & .39 & .32 & 1938 & -1054 & 2552 & -2521 \\ .4 & .37 & .35 & 2018 & -1158 & 3072 & -3907 \\ 1979.1 & .39 & .35 & 1939 & -1079 & 3271 & -3326 \\ .2 & .37 & .33 & 1909 & -853 & 3395 & -3156 \\ .3 & .42 & .27 & 1771 & -643 & 3201 & -2800 \\ .4 & .43 & .23 & 1646 & -505 & 2856 & -2394 \\ 1980.1 & .48 & .19 & 1496 & -426 & 2487 & -2079 \\ .2 & .50 & .17 & 1426 & -415 & 2151 & -1868 \\ .3 & .52 & .16 & 1459 & -475 & 2020 & -1837 \\ .4 & .52 & .16 & 1598 & -516 & 2108 & -1858 \\ 1981.1 & .51 & .15 & 1732 & -456 & 2286 & -1766 \\ .2 & .48 & .15 & 1885 & -471 & 2550 & -1756 \\ .3 & .47 & .14 & 1971 & -435 & 2719 & -1682 \\ .4 & .47 & .15 & 2112 & -508 & 2934 & -1765 \\ 1982.1 & .45 & .15 & 2123 & -536 & 3024 & -1838 \\ .2 & .45 & .17 & 2191 & -669 & 3181 & -2095 \\ .3 & .43 & .18 & 2295 & -747 & 3349 & -2329 \\ .4 & .45 & .20 & 2445 & -905 & 3505 & -2707\end{array}$

note: DC - discount rate DM - foreign rate of interest (DM 3 months deposits) 


\section{Conclusions}

Unfortunately, no firm conclusion can be derived as far as the model needs to be fully integrated with the real economy before this can be done safely. Anyhow, the results seem to depend quite a lot on the sterilization policy of the monetary authorities. If no sterilization takes place the effect of an increased rate of interest is reversed during a five years period. Even though the inflow of liquidity is sterilized leaving the interest at the higher level capital imports nearly dry up due to lower activity and thus demand for credit.

According to the real sector model (SMEC III) it is mainly the bond rate that influences the demand for investment goods and consumption (via the public sector debt). Therefore, a twist in the structure of the interest rate in the direction of relatively lower long-term rates seems to have some advantages regarding activity as well as capital import.

But also in this case it can hardly be stressed too strongly that no empirical results are any better than the underlying model. 
NOTES

1. Bank of Finland has a fully integrated financial and real model based on quarterly data, cf. Tarkka, 1984.

2. One of the main problems carrying out this study was the different time-periods which had been used; ADAM is an annual model whereas NATAN has a half year as the time unit.

3. The so-called 'money market' where private banks deal with cash does sometimes settle a price different from the discount rate (plus 4 per cent), typically when money is in short supply during an exchange crisis; this aspect has not yet been integrated into the model.

4. For 'special deposits'--big deposits for a fixed time period--the interest rate is negotiated more freely, but more often than not the outcome is rather closely related to the terms ruling at the money market.

5. By way of organizing the daily dealing at the bond market government bonds open the market. This forces the central bank to play with open cards, so to speak, from the beginning of the day.

6. This adjustment pattern might be somewhat overstated due to the lack of proper consideration of tax rules. Within the Danish tax system gains can be obtained by stretching the balance sheet.

7. All stocks are calculated at flow values. If one had taken into consideration the drastic fall in bond prices due to the increased rate of interest one would hardly have seen any rise in the amount of bonds held by the p-sector. 
8. Due to portfolio expansion which more than offsets the effect from change in relative rates. Had the feedback from the real sector been taken into account the lower level of investment would have reduced the private supply of bonds.

9. SMEC III is documented in J. Fabritius, 1979. A number of modifications have taken place since, cf. Knudsen, 1984. 
LIST OF LITERATURE

The literature on this topic is vast, below are stated only titles directly referred to in the paper; in addition a few numbers concerning the specific Danish institutions are listed.

BLOMGREN-HANSEN, N.: An Econometric Study of the Financial Sector in Denmark (unpublished), Philadelphia, 1975.

\& J. Petersen: Om stabiliseringspolitikkens begränsninger: simulationer med NATAN (unpublished), Handelshöjskolen i Köbenhavn, 1983.

BRAINARD, W. \& J. Tobin: "Pitfalls in Financial Model Building", American Economic Review, vol. 58, May, 99-122.

BRANSON, W.H.: "Financial Capital Flows in the US Balance of Payments", Amsterdam, 1968.

BRYANT, R.C.: Money and Monetary Policy in Interdependent Nations, Washington, D.C., 1980.

CHRISTENSEN, A.M.: "Pengeefterspфrgselen i Danmark", unpublished, Danmarks Nationalbank, 1984.

ESKESEN, L. e.a.: Finansielle institutioner og markeder, Köbenhavn, 1979 (new edition forthcoming, autumn $1984)$.

ETTLIN, F. e.a.: The STEP-model, Handelshögskolan i stockholm, 1981 .

FABRITIUS, J. e.a.: SMEC III - en simulationsmodel for Danmark, Köbenhavn, 1979.

FRIEDMAN, B.: "Crowding in or Crowding out? Economic Consequences of Financing Government Deficits", Brookings Papers on Economic Activity, 3/1978. 
KNUDSEN, D.: "The Macroeconomic Effects of an Incomes Policy Evaluated by Means of SMEC", paper presented to the seminar on Macroeconomic Modelling, Copenhagen, 1984. LYBECK, J.: A Disequilibrium Model of the Swedish Financial sector, Stockholm, 1975.

ROSTED, J.: "Manфvremuligheder $i$ dansk $\phi$ konomi belyst ved modelsimulationer", memo nr. 103 fra фkonomisk Institut, Kфbenhavns Universitet.

Tarkka, J.: "Monetary Policy in the BOF3 Quarterly Model of the Finnish Economy", Bank of Finland, paper presented to the seminar on Macroeconomic Modelling, Copenhagen, 1984 . 


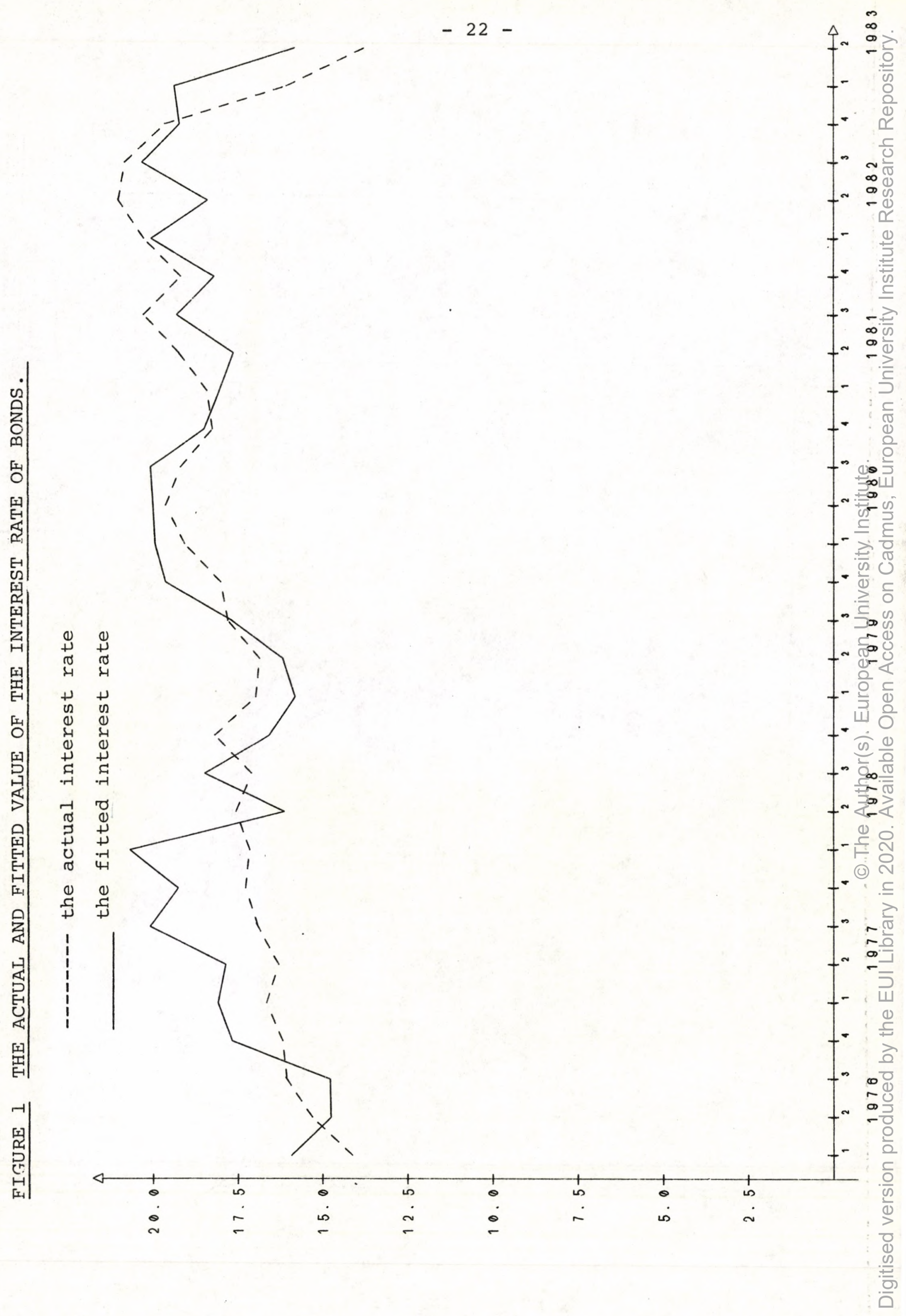




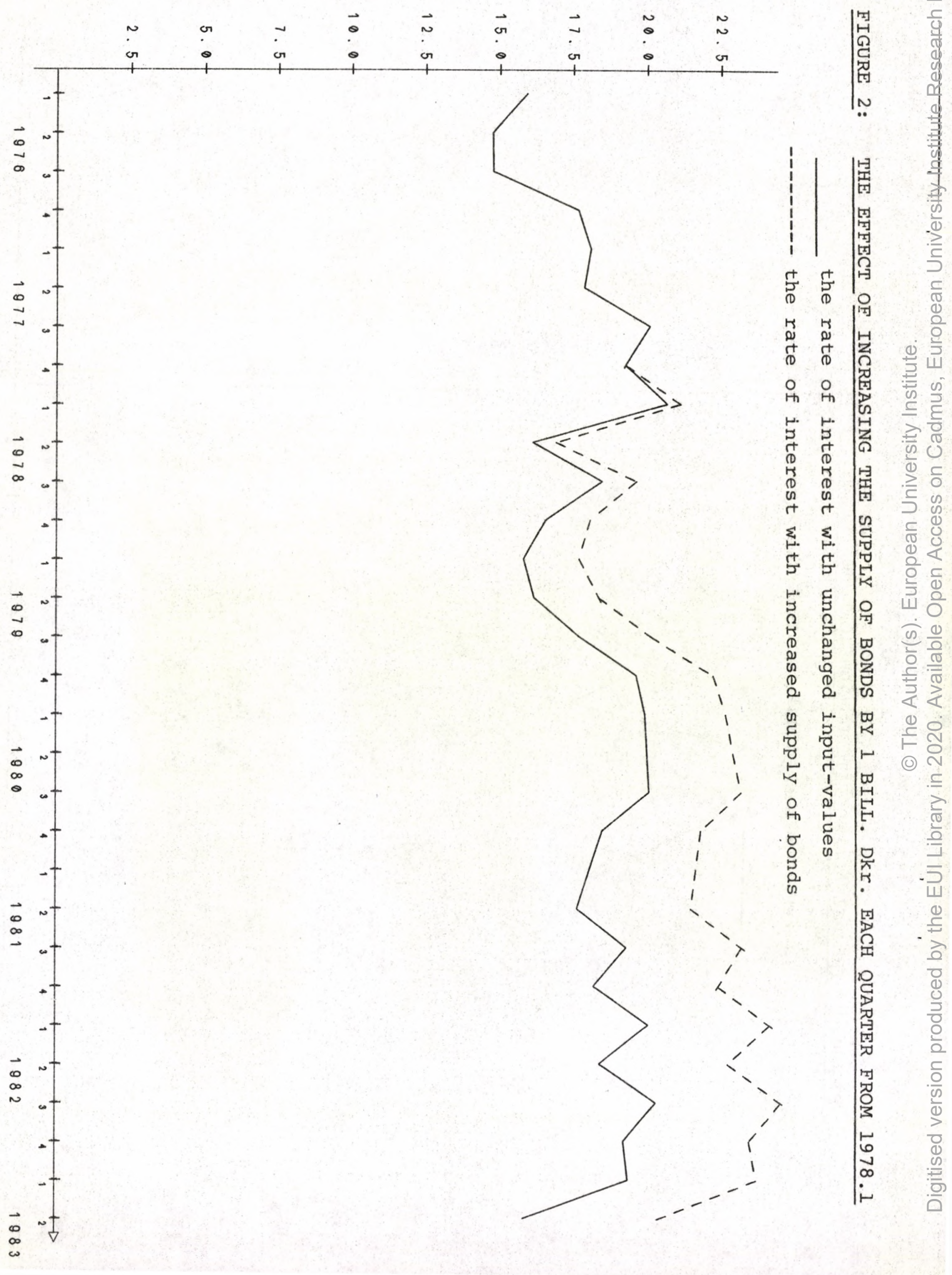


List of (Main) Variables

All endogenous variables are explained in the listing of the model. Accordingly, only the more important exogenous variables will be mentioned below:

DUMIN Durmy taking into account the introduction of treasury bills in 1976

DUM1,2,3,4 Seasonal dummies

EDM German/Danish exchange rate

IDM3 DM rate of interest

IDI Danish discount rate

Y GDP

IH Investments in housing

IF Gross investments

BBLBAL Current account on the balance of payments $t_{+}=$ deficit)

STABAL Central government balance (- = deficit)

KOMBAL Local government balance

NATBAL Central Bank Balance

IDD Demand deposit interest rate

ITD Time deposit interest rate

ILO Load interest rate

SBALBO The amount of the government deficit financed by bonds

BOGXU The supply of government bonds (incl. treasury bilis)

PWEX Total financial assets held by private sector

IBO Bond interest rate

PWEPX Private sector financial net wealth

PDTDB Private sector bank deposits 


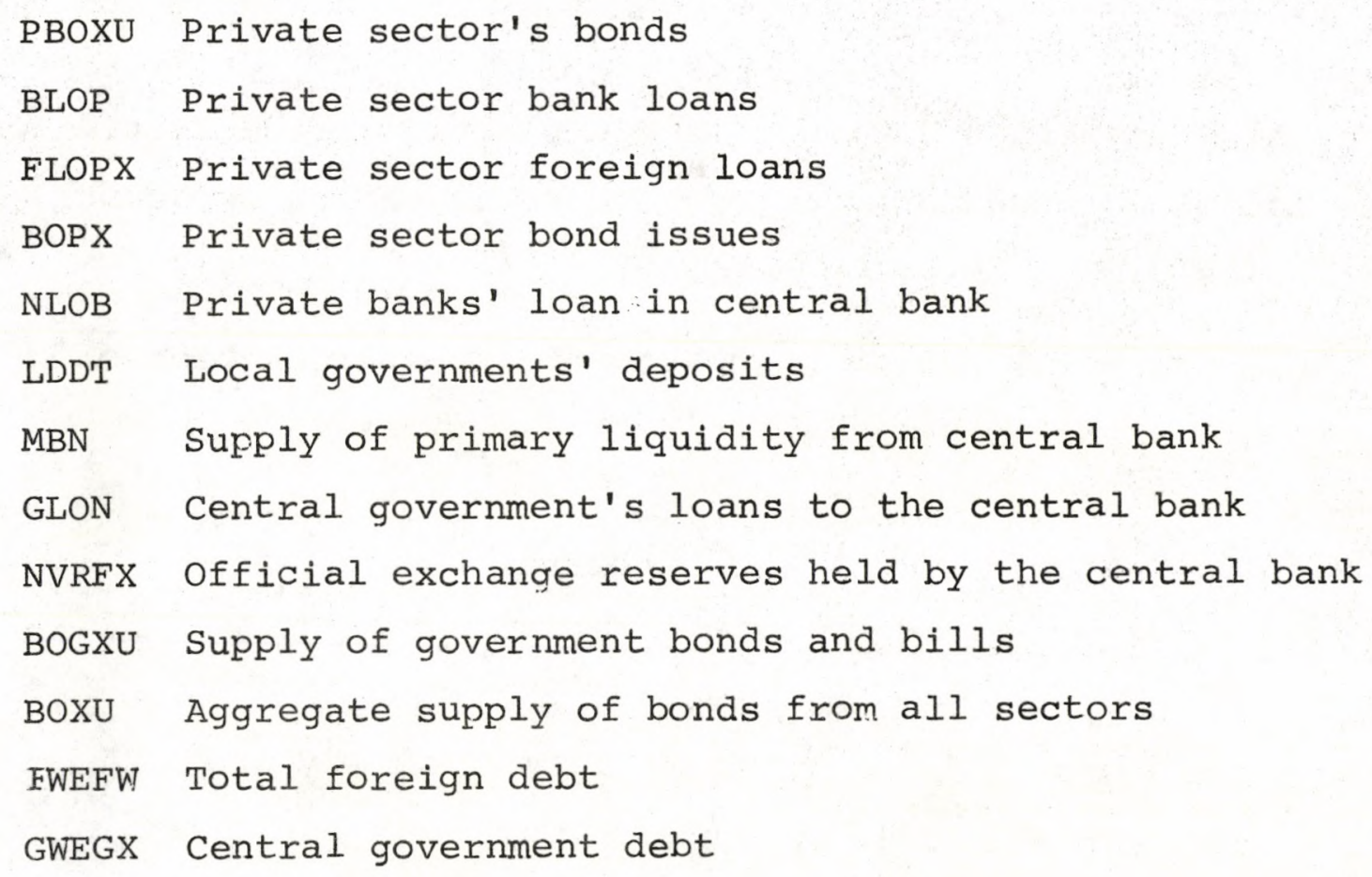

All stocks are accounted in values of actuated flows and in mill. Dkr.

Interest rates are presented as percentage points. Exchange rate DKR./DM.

Dummies have the value of 1 when they are activated. 


\section{ANNEX 1}

FINDAN - a Financial-sector Model for the Danish Economy (estimated on quarterly data from 1973. to 1982.4)

1. Private non-financial sector (P-sector)

a. ASSETS

Demand for Primary Liquidity (PMBN)

EI00 KPMBN $=-.0661+.38 * \mathrm{Y} / \mathrm{PWEX}(-1)-.00181 *($ ITD-IDI $)+$ EII0 PMBN $=$ KPMBN*PWEX $(-1) \$$

Demand for Bank Deposits (PDTDB)

$$
\begin{aligned}
& \operatorname{PDTDB}=\operatorname{EXP}(.3694) *((.4 * Y+.3 * Y(-1)+.2 * Y(-2)+.1 * Y(-\ddot{3})) * * 1.273) * \\
& ((100 * \operatorname{EDM}(-1) / \operatorname{EDM}(-5)) * *(-.6516)) * \\
& ((.4 * \operatorname{IDM} 3+.3 * \operatorname{IDM} 3(-1)+.2 * \operatorname{IDM} 3(-2)+.1 * \operatorname{IDM} 3(-3)) * *(-.081) \\
& ((.4 * I B O+.3 * I B O(-1)+.2 * I B O(-2)+.1 * I B O(-3)) * *(-.34)) * \\
& ((P W E P X+100000) * * .0385) \$ \\
& +.0272 * \text { DUMIN-. } 023 *(\operatorname{EDM}(-1) / \operatorname{EDM}(-5)-1)+ \\
& +.0627 * \text { PWEPX/PWEX }(-1) \$
\end{aligned}
$$

Total Assets

E150 PWEX =PMBN+PDTDB+PBOXU+BWEBX+PLOL\$

\section{b. IIABILITIES}

Bank Loans (BLOP)

$\begin{aligned} & \text { E160 KBLOP }= .116+.6157 * I H / Y+.6304 * \mathrm{Y} / \mathrm{PWEX}(-1) \\ &-.1014 * \operatorname{PWEPX}(-1) / \mathrm{PWEX}(-2) \$ \\ & \text { E170 BLOP }=\mathrm{KBLOP} \text { PWEX }(-1) \$\end{aligned}$

Foreign Loans (FLOP)

E200 FLOPX =WEPX-BLOP-BOPX-GLOP-HLOP-ELOP\$

\section{Bond Issues (BOFX)}

E210 KBOPX $=.56+1.2874 * \operatorname{IF} / \mathrm{PWEX}(-1)-.0037 *($ IBO- $.5 * I L O)-$

E230 BOPX $=\begin{aligned} & 4804 * \operatorname{KBOPEPX} / \operatorname{PWEX}(-1) \$ \\ & \text { KWWX }(-1) \$\end{aligned}$

Financial net wealth (PWEPX)

E250 PWEPX =-BBLBAL-STABAL-NATBAL-KOMBAL+PWEPX $(-1) \$$

Total Liabilities (WEPX)

E260 WEPX =PWEX-PWEPXS 
2. Private Banks (B-sector)

a. RATES OF INTEREST

Demand Deposits (IDD)

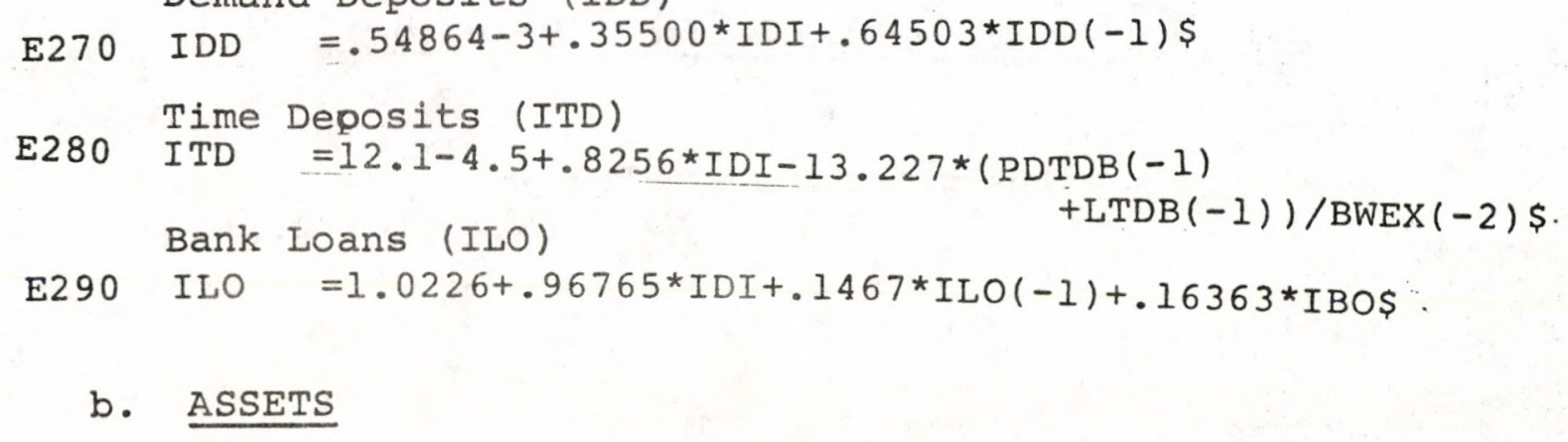

Demand for Primary Liquidity (BMBN)

E330 $\mathrm{KBMBN}=.00666 *(\mathrm{LTDB}+\mathrm{PDTDB}+\mathrm{LDDB}) / \mathrm{BWEX}+524.0822 *(1 / \mathrm{BWEX})$

E340 BMBN $\begin{aligned} & -.004 * \text { KBMMI } \\ & \text { KBMN BWEX } \$\end{aligned}$

Bond Holdings (BBOXU)

E350 DKBOXU $=2.4-5.199 *($ ILO-ILO $(-1))+$ $392.859 *(\operatorname{LIK} / \operatorname{BWEX}(-1)-\operatorname{LIK}(-1) / \operatorname{BWEX}(-2)) \$$

E360 KBBOXU $=$ DKBOXU $/ 1000+\operatorname{KBBOXU}(-1) \$$

E370 BBOXU $=$ KBBOXU*BWEX $(-1) \$$

E380 LIK =PDTDB+LDDB+LTDB+FDEB-BLOP-BLOL-BLOF\$

Total Assets (BWEX)

E390 BWEX = BMBN+BVRFX+BDEN+BLOP+BLOL+BLOF+BBOXU+BBOF\$

c. IIABILITIES

Loans in the central Bank (NLOB)

E300 NLOB =BMBN+BVRFX+BDEN+BLOP+BLOL+BLOF+BBOXU+BBOF-PDTDBLDDB-LTDB-FDEB-FLOB-BWEBX\$

Total Liabilities (except net wealth) (WEBX)

E310 WEBX =PDTDB+LDDB+LTDB+FDEB+NLOB+FLOB

Financial net Wealth (BWEBX)

E320 BWEBX $=$ BWEBX $(-1)+$ PIBAL $\$$

3. The Bond Market

Interest Rate (IBO)

E440 IBO $=1 /(\operatorname{PWEX}(-1) * .0062) *($ BOLX +BOGXU-LBOX-NBOX-GBOXU

$-\mathrm{FBOX}-\mathrm{BBOXU}+\mathrm{PWEX}(-1) *(.56+1.2874 * \operatorname{IF} / \mathrm{PWEX}(-1)+.0037 * .5$

*ILO-. 48 * PWEPX/PWEX $(-1))$

$-\operatorname{PWEX}(-1) *(.361+.0049 *$ I BO $(-1)+.0092 *$ DUM $2+.0272 *$ DUMIN $-.023 *$

$(\operatorname{EDM}(-1) / \operatorname{EDM}(-5)-1)+.0627 * \operatorname{PWEPX} / \operatorname{PWEX}(-1))) \$$ 
ANNEX 2

Input data for the 'real' variables and supply of additional bonds (SBAIBO)

\begin{tabular}{|c|c|c|c|c|c|c|c|}
\hline period & $Y$ & IF & IF & BBLBAL & STABAL & SBA & $\mathrm{BO}$ \\
\hline & & & & & & 1. & 2 . \\
\hline & $-\cdots$ & $\ldots$ & $\cdots$ & 1. $\mathrm{kr}$. & $-m$ & $\cdots$ & -- \\
\hline 1978.1 & 0 & 0 & 0 & 0 & 0 & 2500 & 2500 \\
\hline .2 & -5 & 0 & -20 & -20 & -10 & 0 & 30 \\
\hline .3 & -15 & 0 & -40 & -40 & -25 & 0 & 65 \\
\hline .4 & -28 & -3 & -70 & -70 & -60 & 0 & 130 \\
\hline 1979.1 & -172 & -150 & -225 & -125 & -135 & 0 & 260 \\
\hline .2 & -192 & -150 & -243 & -150 & -145 & 0 & 295 \\
\hline .3 & -233 & -150 & -332 & -200 & -150 & 0 & 350 \\
\hline .4 & -253 & -142 & -350 & -225 & -150 & 0 & 375 \\
\hline 1980.1 & -260 & -131 & -330 & -230 & -150 & 0 & 380 \\
\hline .2 & -280 & -131 & -330 & -240 & -150 & 0 & 390 \\
\hline .3 & -321 & -131 & -330 & -250 & -150 & 0 & 400 \\
\hline .4 & -341 & -131 & -330 & -255 & -150 & 0 & 405 \\
\hline 1981.1 & -361 & -110 & -325 & -265 & -154 & 0 & 419 \\
\hline .2 & -371 & -110 & -325 & -275 & -154 & 0 & 429 \\
\hline .3 & -371 & -110 & -325 & -285 & -154 & 0 & 439 \\
\hline .4 & -381 & -110 & -325 & -295 & -154 & 0 & 449 \\
\hline 1982.1 & -395 & -93 & -310 & -288 & -161 & 0 & 449 \\
\hline .2 & -400 & -92 & -290 & -278 & -161 & 0 & 439 \\
\hline .3 & -410 & -92 & -270 & -268 & -161 & 0 & 429 \\
\hline .4 & -415 & -92 & -241 & -258 & -161 & 0 & 419 \\
\hline
\end{tabular}

$\mathrm{Y}$ - GDP IF - Total investments

IH - Investments in new houses

BBLBAI - Balance of Payments Current Account (- = reduced deficit) STABAJ - Public sector balance (- = increased deficit) 
No. 1: Jacques PELKMANS

No. 3: Aldo RUSTICHINI

No. 9: Manfred E. STREIT

No. 10: Kumaraswamy VELUPILLAI

No. 11: Kumaraswamy VELUPILLAI

No. 12: Kumaraswamy VELUPILLAI Guglie1mo CHIODI

No. 22: Don PATINKIN

No. 23: Marcello DE CECCO

No. 24: Marce1lo DE CECCO

No. 25: Manfred E. STREIT

No. 26: Domenico Mario NUTI

No. 34: Jean-Paul FITOUSSI

No. 35: Richard M. GOODWIN Kumaraswamy VELUPILLAI

No. 46: Alessandra VENTURINI

No. 47: Richard M. GOODWIN

No. 48: Jean-Paul FITOUSSI Danie1 SZPIRO

No. 56: Berc RUSTEM Kumaraswamy VELUPILLAI

No. 60: Jean-Paul FITOUSSI

No. 64: Marcello DE CECCO
The European Community and the Newly Industrialized Countries

Seasonality in Eurodollar Interest Rates

Information Processing in Futures Markets. An Essay on the Adequacy of an Abstraction.

When Workers Save and Invest: Some Kaldorian Dynamics

A Neo-Cambridge Model of Income Distribution and Unemployment

On Lindahl's Theory of Distribution

Pau1 A. Samuelson on Monetary Theory

Inflation and Structural Change in the Euro-Dollar Market

The Vicious/Virtuous Circle Debate in the '20s and the '70s

Modelling, Managing and Monitoring Futures Trading: Frontiers of Analytical Inquiry

Economic Crisis in Eastern Europe: Prospects and Repercussions

Modern Macroeconomic Theory; an Overview

Economic Systems and their Regulation

Is the Bargaining Theory Still an Effective Framework of Analysis for Strike Patterns in Europe?

Schumpeter: The Man I Knew

Politique de l'Emploi et Réduction de la Durée du Travail

Preferences in Policy Optimization and Optimal Economic Policy

Adjusting to Competitive Depression. The Case of the Reduction in Working Time

Italian Monetary Policy in the 1980s 
No. 65: Gianpaolo ROSSINI

No. 66: Wolfgang GEBAUER

No. 67: Gerd WEINRICH

No. 68: Sau1 ESTRIN Derek C. JONES

No. 69: Berc RUSTEM Kumaraswamy VELUPILLAI

No. 72: Wolfgang GEBAUER

No. 75: Sheila A. CHAPMAN

No. 90: Will BARTLETT

No. 91: Wo1fgang GEBAUER

No. 92: Elisabeth DE GELLINCK Pau1 A. GEROSKI Alexis JACQUEMIN

84/103: Marcello DE CECCO

84/105: Derek C. JONES

84/111: Jean-Paul FITOUSSI Kumaraswamy VELUPILLAI

84/113: Domenico Mario NUTI

84/114: Sau1 ESTRIN Jan SVEJNAR

84/116: Reinhard JOHN
Intra-industry Trade in Two areas: Some Aspects of Trade Within and Outside a Custom Union

Euromarkets and Monetary Control: The Deutschmark Case

On the Theory of Effective Demand under Stochastic Rationing

The Effects of Worker Participation upon Productivity in French Producer Cooperatives

On the Formalization of Political Preferences: A Contribution to the Frischian Scheme

Inflation and Interest: the Fisher Theorem Revisited

Eastern Hard Currency Debt 19701983. An Overview.

Unemployment, Migration and Industrialization in Yugoslavia, 1958-1982

Kondratieff's Long Waves

Inter-Industry and Inter-Temporal Variations in the Effect of Trade on Industry Performance

The International Debt Problem in the Interwar Period

The Economic Performance of Producer Cooperatives within Command Economies: Evidence for the Case of Poland

A Non-Linear Model of Fluctuations in Output in a Mixed Economy

Mergers and Disequilibrium in LabourManaged Economies

Explanations of Earnings in Yugoslavia: the Capital and Labor Schools Compared

On the Weak Axiom of Revealed Preference Without Demand Continuity Assumptions 
84/118: Pierre DEHEZ

84/119: Domenico Mario NUTI

84/120: Marcello DE CECCO

84/121: Marce11o DE CECCO

84/122: Marce11o DE CECCO

84/123: Lione11o PUNZ0 Kumaraswamy VELUPILLAI

84/126: John CABLE

84/127: Jesper JESPERSEN
Monopolistic Equilibrium and Involuntary Unemployment

Economic and Financial Evaluation of Investment Projects: General Principles and E.C. Procedures

Monetary Theory and Roman History

International and Transnational Financial Relations

Modes of Financial Development: American Banking Dynamics and World Financial Crises

Multisectoral Models and Joint Production

Employee Participation and Firm Performance : a Prisoners' Dilemma Framework

Financial Model Building and Financial Multipliers of the Danish Economy

Spare copies of these Working Papers can be obtained from:

Secretariat Economics Department

European University Institute

Badia Fiesolana

50016 S. Domenico di Fiesole (Fi)

Italy 


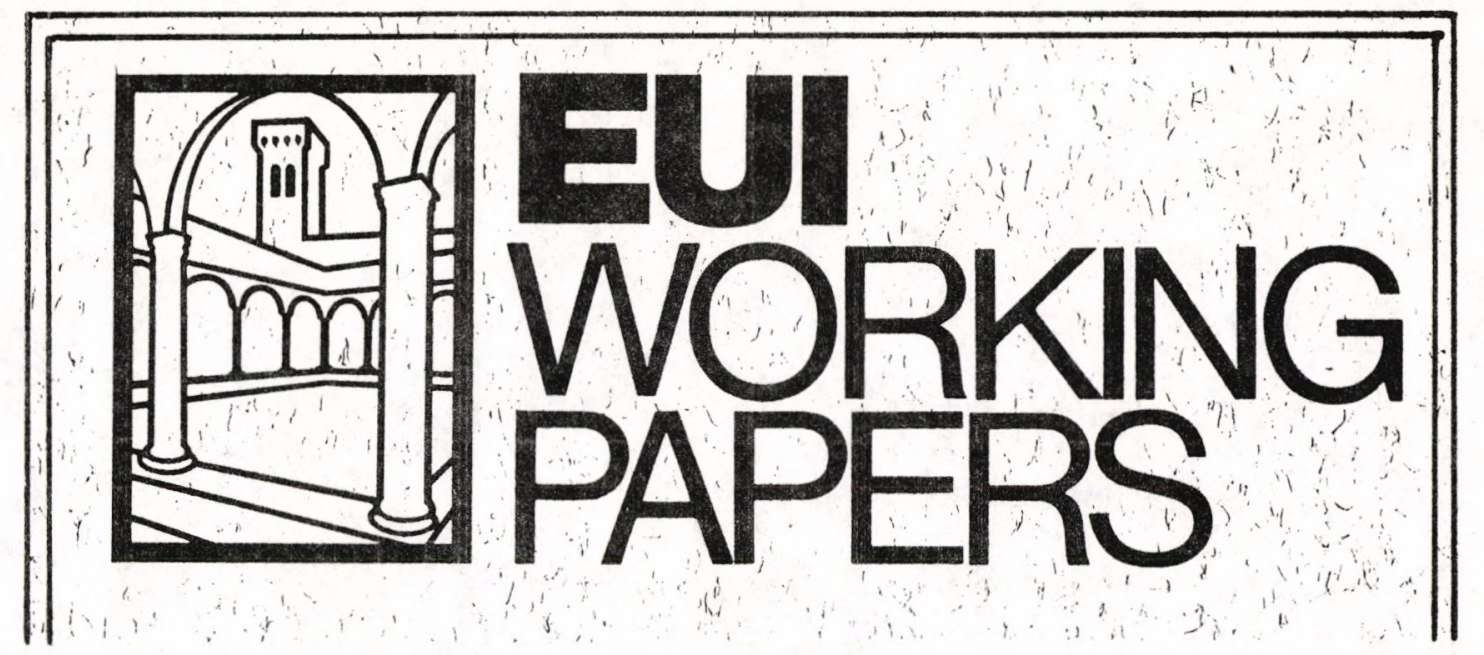

EUI Working Papers are published and distributed by the European University Institute, Florence.

Copies can be obtained free of charge -- depending on the availability of stocks -- from:

The Publications Officer

European University Institute

Badia Fiesolana

I-50016 San Domenico di Fiesole(FI)

Italy

Please use order form overleaf. 
To

\author{
: The Publications officer \\ European University Institute \\ Badia Fiesolana \\ I-50016 San Domenico di Fiesole(FI) \\ Italy
}

From

: Name.......................

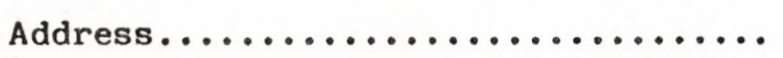

Please send me the following EUI Working Paper(s):

No.: $\ldots \ldots \ldots \ldots \ldots \ldots$

Author, title:

Date:

Signature: 


\section{PUBLICATIONS OF THE EUROPEAN UNIVERSITY INSTITUTE}

EUI WORKING PAPERS

1: Jacques PELKMANS

2: Joseph H.H. WEILER

3: Aldo RUSTICHINI

4: Mauro CAPPELLETTI/ David GOLAY

5: Leonard GLESKE

6: Manfred HINZ

7: Wilhelm BURKLIN

8: Athanasios MOULAKIS

9: Manfred E. STREIT

10:Kumaraswamy VELUPILLAI

11 :Kumaraswamy VELUPILLAI

12:Kumaraswamy VELUPILLAI/ Guglielmo CHIODI

13: Gunther TEUBNER

14: Gunther TEUBNER

15: Jens ALBER
The European Community and the Newly Industrialized Countries

Supranationalism Revisited Retrospective and Prospective. The European Communities After Thirty Years

Seasonality in Eurodollar Interest Rates

Judicial Review, Transnational and

Federal: Impact on Integration

The European Monetary System: Present Situation and Future Prospects

Massenkult und Todessymbolik in der national-sozialistischen Architektur

The "Greens" and the "New Politics": Goodbye to the Three-Party System?

Unilateralism or the Shadow of Confusion

Information Processing in Futures Markets. An Essay on the Adequacy of an Abstraction

When Workers Save and Invest: Some Kaldorian Dynamics

A Neo-Cambridge Model of Income Distribution and Unemployment

On Lindahl's Theory of Distribution

Reflexive Rationalitaet des Rechts

Substantive and Reflexive Elements in Modern Law

Some Causes and Consequences of Social Security Expenditure Development in Western Europe, 1949-1977 
16: Ian BUDGE

17:Hans DAALDER

18:Giuseppe DI PALMA

$19:$ Richard S. KATZ

20:Juerg STEINER

21:Jens ALBER

22:Don PATINKIN

23: Marcello DE CECCO

24:Marcello DE CECCO

25:Manfred E. STREIT

26:Domenico Mario NUTI

27:Terence C. DAINTITH

28: Frank C. CASTLES/

Peter MAIR

29:Karl HOHMANN

30: Max KAASE
Democratic Party Government: Formation and Functioning in Twenty-One Countries

Parties and Political Mobilization: An Initial Mapping

Party Government and Democratic Reproducibility: The Dilemma of New Democracies

Party Government: A Rationalistic Conception

Decision Process and Policy Outcome: An Attempt to Conceptualize the Problem at the Cross-National Level

The Emergence of Welfare Classes in West Germany: Theoretical Perspectives and Empirical Evidence

Paul A. Samuelson and Monetary Theory

Inflation and Structural Change in the Euro-Dollar Market

The Vicious/Virtuous Circle Debate in the 120 s and the 170 s

Modelling, Managing and Monitoring Futures Trading: Frontiers of Analytical Inquiry

Economic Crisis in Eastern Europe Prospects and Repercussions

Legal Analysis of Economic Policy

Left-Right Political Scales: Some Expert Judgements

The Ability of German Political Parties to Resolve the Given Problems: the Situation in 1982

The Concept of Political Culture: Its Meaning for Comparative Political Research 
$31:$ Klaus TOEPFER

32: Ronald INGLEHART

33: Moshe LISSAK

34: Jean-Paul FITOUSSI

35: Richard M. GOODWIN/ Kumaraswamy VELUPILLAI

36: Maria MAGUIRE

$37:$ G. LOWELL FIELD/ John HIGLEY

38:Dietrich HERZOG

39:Edward O. LAUMANN/ David KNOKE

40: Gwen MOOR/ Richard D. ALBA

$41:$ Peter MAIR

42: Joseph H.H. WEILER

43: Franz Urban PAPPI

44: Thomas GAWRON/ Ralf ROGOWSKI
Possibilities and Limitations of a Regional Economic Development Policy in the Federal Republic of Germany

The Changing Structure of Political Cleavages Among West European Elites and Publics

Boundaries and Institutional Linkages Between Elites: Some Illustrations from Civil-Military Elites in Israel

Modern Macroeconomic Theory: An Overview

Economic Systems and their Regulation

The Growth of Income Maintenance Expenditure in Ireland, 1951-1979

The States of National Elites and the Stability of Political Institutions in 81 Nations, 1950-1982

New Protest Elites in the Political System of West.Berlin: The Eclipse of Consensus?

A Framework for Concatenated Event Analysis

Class and Prestige Origins in the American Elite

Issue-Dimensions and Party Strategies in the Irish republic, 1948-1981: The Evidence of Manifestos

Israel and the Creation of a Palestine State. The Art of the Impossible and the Possible

Boundary Specification and Structural Models of Elite Systems: Social Circles Revisited

Zur Implementation von

Gerichtsurteilen. Hypothesen zu den Wirkungsbedingungen von Entscheidungen des Bundesverfassungsgerichts 
45: Alexis PAULY/

René DIEDERICH

46: Alessandra VENTURINI

47:Richard A. GOODWIN

48:J.P. FITOUSSI/

Daniel SZPIRO

49:Bruno DE WITTE

50:Massimo A. BENEDETTELLI

51 : Gunther TEUBNER

52: Erich SCHANZE

53:Maurizio COTTA

54: Mattei DOGAN

55:Mariano BAENA DEL ALCAZAR/ Narciso PIZARRO

$56:$ Berc RUSTEM/ Kumaraswamy VELUPILLAI

57: Giorgio FREDDI

59: Christopher Hill/ James MAYALL
Migrant Workers and Civil Liberties

Is the Bargaining Theory Still an Effective Framework of Analysis for Strike Patterns in Europe?

Schumpeter: The Man I Knew

Politique de 1'Emploi et Réduction de la Durée du Travail

Retour à Costa. La Primauté du Droit Communautaire à la Lumière du Droit International

Eguaglianza e Libera Circolazione dei Lavoratori: Principio di Eguaglianza e Divieti di Discriminazione nella Giurisprudenza Comunitaria in Materia di Diritti di Mobilità Territoriale e Professionale dei Lavoratori

Corporate Responsability as a Problem of Company Constitution

Potentials and Limits of Economic Analysis: The Constitution of the Firm

Career and Recruitment Patterns of Italian Legislators. A Contribution of the Understanding of a Polarized System

How to become a Cabinet Minister in Italy: Unwritten Rules of the Political Game

The Structure of the Spanish Power Elite 1939-1979

Preferences in Policy Optimization and Optimal Economic Policy

Bureaucratic Rationalities and the Prospect for Party Government

The Sanctions Problem: International and European Perspectives 
60:Jean-Paul FITOUSSI

61 :Philippe LEFORT

62:Peter BROCKMEIER

63:Hans-Martin PAWLOWSKI

64:Marcello DE CECCO

65:Gianpaolo ROSSINI

66:Wolfgang GEBAUER

67:Gerd WEINRICH

68:Saul ESTRIN/

Derek C. JONES

69:Berc RUSTEM

Kumaraswamy VELUPILLAI

70:Werner MAIHOFER

$71:$ Samuel $\mathrm{COHN}$

72:Wol fgang GEBAUER

73: Patrick NERHOT

$74:$ Philippe SCHMITTER

75 : Sheila A. CHAPMAN
Adjusting to Competitive Depression. The Case of the Reduction in Working Time

Idéologie et Morale Bourgeoise de la Famille dans le Ménager de Paris et le Second Libro di Famiglia, de L.B. Alberti

Die Dichter und das Kritisieren

Law and Social Conflict

Italian Monetary Policy in the 1980s

Intraindustry Trade in Two Areas: Some Aspects of Trade Within and Outside a Custom Union

Euromarkets and Monetary Control: The Deutschemark Case

On the Theory of Effective Demand under Stochastic Rationing

The Effects of Worker Participation upon Productivity in French Producer Cooperatives

On the Formalization of Political Preferences: A Contribution to the Frischian Scheme

Politique et Morale

Five Centuries of Dying in Siena: Comparison with Southern France

Inflation and Interest: the Fisher Theorem Revisited

Rationalism and the Modern State

Democratic Theory and Neo-Corporatist Practice

Eastern Hard Currency Debt 1970-83. An Overview 
76:Richard GRIFFITHS

77: Scott NEWTON

78: Giorgio FODOR

79:Philippe MIOCHE

80: Werner ABELSHAUSER

81:Helge PHARO

$82:$ Heiner R. ADAMSEN

83: Jean BOUVIER

84: Mariuccia SALVATI

85:William DIEBOLD, Jr.

86:Frances LYNCH

87: Gunther TEUBNER

88:Maria SPINEDI

$89:$ Jelle VISSER

90:Will BARTLETT

91:Wolfgang GEBAUER
Economic Reconstruction Policy in the Netherlands and its International Consequences, May 1945 - March 1951

The 1949 Sterling Crisis and British Policy towards European Integration

Why did Europe need a Marshall Plan in 1947?

The Origins of the Monnet Plan: How a Transistory Experiment answered to Deep-Rooted Needs

The Economic Policy of Ludwig Erhard

The Domestic and International Implications of Norwegian Reconstruction

Investitionspolitik in der Bundesrepublik Deutschland 1949-1951

Le Plan Monnet et I'Economie Française 1947-1952

Industrial and Economic Policy in the Italian Reconstruction

Trade and Payments in Western Europe in Historical Perspective: A Personal View by an Interested Party

French Reconstruction in a European Context

Verrechtlichung. Begriffe, Merkmale, Grenzen, Auswege

Les Crimes Internationaux de l'Etat dans les Travaux de Codification de la Responsabilité des Etats Entrepris par les Nations Unies

Dimensions of Union Growth in Postwar Western Europe

Unemployment, Migration and Industrialization in Yugoslavia, 19581977

Kondratieff's Long Waves 


\author{
92: Elisabeth DE GHELLINCK/ \\ Paul A. GEROSKI/ \\ Alexis JACQUEMIN \\ 93: Gunther TEUBNER/ \\ Helmut WILLKE

\section{4:Wolfgang STREECK/ Philippe C. SCHMITTER}

\section{5: Nigel GRIFFIN}

96: Andreas KUNZ

97: Wol fgang STREECK

98: Simon A. HORNER

99:Daniel ROCHE

84/100: Gunther TEUBNER

84/101: Patrick NERHOT

84/102: Jelle VISSER

84/103:Marcello DE CECCO

84/104:M. Rainer LEPSIUS
Inter-Industry and Inter-Temporal Variations in the Effect of Trade on Industry Performance

Kontext und Autonomie.

Gesellschaftliche Selbststeuerung durch Reflexives Recht

Community, Market, State- and Associations. The Prospective Contribution of Interest Governance to Social Order

"Virtue Versus Letters": The Society of Jesus 1550-1580 and the Export of an Idea

Arbeitsbeziehungen und Arbeitskonflikte im oeffentlichen Sektor. Deutschland und Grossbritannien im Vergleich 1914-1924

Neo-Corporatist Industrial Relations and the Economic Crisis in West Germany

The Isle of Man and the Channel Islands - A Study of their Status under Constitutional, International and European Law

Le Monde des Ombres

After Legal Instrumentalism?

Contribution aux Débats sur le Droit Subjectif et le Droit Objectif comme Sources du Droit

The Position of Central Confederations in the National Union Movements

The International Debt Problem in the Inter-War Period

Sociology in Germany and Austria 19181945. The Emigration of the Social Sciences and its Consequences. The Development of Sociology in Germany after the Second World War, 1945-1967 
84/105: Derek JONES

84/106:Philippe C. SCHMITTER

$84 / 107:$ Marcos BUSER

84/108:Frans van WAARDEN

84/109: Ruggero RANIERI

$84 / 110:$ Peter FARAGO

84/111: Jean-Paul FITOUSSI/ Kumuraswamy VELUPILLAI

84/112: Anna Elisabetta GALEOTTI

84/113: Domenico Mario NUTI

84/114: Saul ESTRIN/Jan SVEJNAR

84/115: Alan CAWSON/John BALLARD

84/116: Reinhard JOHN

84/117:Richard T.GRIFFITHS/Frances M.B. LYNCH

84/118:Pierre DEHEZ

84/119: Domenico Mario NUTI

84/120: Marcello DE CECCO
The Economic Performances of Producer Cooperations within Command Economies: Evidence for the Case of Poland

Neo-Corporatism and the State

Der Einfluss der Wirtschaftsverbaende auf Gesetzgebungsprozesse und das Vollzugswesen im Bereich des Umweltschutzes

Bureaucracy around the State:Varieties of Collective Self-Regulation in the Dutch Dairy Industry

The Italian Iron and Steel Industry and European Integration

Nachfragemacht und die kollektiven Reaktionen der Nanrungsmittelindustrie

A Non-Linear Model of Fluctuations in Output in a Mixed Economy

Individualism and Political Theory

Mergers and Disequilibrium in LabourManaged Economies

Explanations of Earnings in Yugoslavia: The Capital and Labor Schools Compared

A Bibliography of Corporatism

On the Weak Axiom of Revealed Preference Without Demand Continuity Assumptions

The FRITALUX/FINEBEL Negotiations $1949 / 1950$

Monopolistic Equilibrium and Involuntary Unemployment

Economic and Financial Evaluation of Investment Projects; General Principles and E.C. Procedures Monetary Theory and Roman History 
84/121:Marcello DE CECCO

84/122:Marcello DE CECCO

84/123:Lionello F. PUNZ0/ Kumuraswamy VELUPILLAI

84/124: John FARQUHARSON

84/125: Ian HARDEN/Norman LEWIS

84/126: John CABLE

84/127: Jesper JESPERSEN

84/128:Ugo PAGANO

84/129: Maureen CAIN

85/130: Otfried HOEFFE

85/131: Stuart J. WOOLF

85/132: Massimo MARCOLIN.

85/133: Osvaldo RAGGIO

85/134:Renzo SABBATINI

85/135: Sabine JURATIC
International and Transnational Financial Relations

Modes of Financial Development: American Banking Dynamics and World Financial Crises

Multisectoral Models and Joint Production

The Management of Agriculture and Food Supplies in Germany, 1944-47

De-Legalisation in Britain in the 1980s

Employee Participation and Firm Performance. A Prisoners' Dilemma Framework

Financial Model Building and Financial Multipliers of the Danish Economy

Welfare, Productivity and SelfManagement

Beyond Informal Justice

Political Justice - Outline of a Philosophical Theory

Charity and Family Subsistence: Florence in the Early Nineteenth Century

The Casa d'Industria in Bologna during the Napoleonic Period: Public Relief and Subsistence Strategies

Strutture di parentela e controllo delle risorse in un'area di transito: la Val Fontanabuona tra Cinque e Seicento

Work and Family in a Lucchese PaperMaking Village at the Beginning of the Nineteenth Century

Solitude féminine et travail des femmes à Paris à la fin du XVIIIème 
siècle

85/136: Laurence FONTAINE

85/137: Chris topher JOHNSON

85/138: Daniela LOMBARDI
Les effets déséquilibrants du colportage sur les structures de famille et les pratiques économiques dans la vallée de l'Oisans, 18e-19e siècles

Artisans vs. Fabricants: Urban Protoindustrialisation and the Evolution of Work Culture in Lodève and Bédarieux, 1740-1830

La demande d'assistance et les réponses des autorités urbaines face à une crise conjoncturelle: Florence 1619-1622 
